\title{
LEARNING DIFFICULTIES OF CHILDREN WITH EMIGRANT PARENTS ${ }^{8}$
}

$\begin{array}{cc}\text { Authors: } & \text { Lectors: } \\ \text { Cristina Catalano } & \text { Horatiu Catalano } \\ \text { Babes Bolyai University (Cluj Napoca, } & \text { Babes Bolyai University (Cluj Napoca, } \\ \text { Romania) } & \text { Romania) } \\ & \text { Magdolna Nemes } \\ & \text { Babes Bolyai University (Cluj Napoca, } \\ & \text { Romania) } \\ \text { E-mail address of the first author: } & \text { Veronika Schéder } \\ \text { cris25_catalano@yahoo.com } & \text { University of Debrecen } \\ & \text { Katalin Mezö }\end{array}$

Cristina Catalano (2017): Learning difficulties of children with emigrant parents. Különleges Bánásmód, III. évf. 2017/1. szám, 87-93. DOI 10.18458/KB.2017.1.87

\begin{abstract}
In the beginning of the 21st century a lot of Romanian parents leave their country to work abroad. While they are away grandparents or other relatives look after their children. The pranets and their children keep in touch via Skype, Viber or other technology that allows verbal communication only. It has turned out that the parents' leaving impacts on children as they have a lot of psychological problems. Moreover, they have differents learning difficulties and have behavioral problems at school. The solution to solve the problem could be special methods for children with learning difficulties.
\end{abstract}

Keywords: a kulcsszavak angol nyelvü fordítása

Disciplines: a diszciplinák angol nyelvü fordítása

\section{Absztrakt}

A 21. század elején sok román szülő hátrahagyja gyermekét/gyermekeit, külföldön keres megélhetést. A szülők távollétében a gyerekekt a nagyszülők vagy más rokonok nevelik. A szülők és gyermekeik Skype-on, Viberen tartják egymással a kapcsolatot, ám ez a csatorna csak a verbális kommunikációt teszi lehetővé. A gyerekeket megviseli a szülök tartós hiánya, különféle pszchológiai problémák lépnek fel náluk. A gyerekek körében tanulási

\footnotetext{
${ }^{8}$ The editorial board does not take any responsibilty for the English of the papers. Indeed, we made some slight changes but wanted to keep the style of the authors.
} 
nehézségeket is megfigyeltek. A helyzet megoldására a felkészült tanárok és a megfelelő módszerek adhatják meg a választ.

Kulcsszavak: kulcsszó1, kulcsszó2, kulcsszó3, kulcsszó4

Diszciplína: pl. gyógypedagógia, pszichológia, jogtudomány stb.

\section{THE EMIGRATION OF PEOPLE FROM ROMANIA- A FAMILY PROBLEM}

The Romanians' 'gold rush' in the $21^{\text {st }}$ century is the exodus of unemployed people. They go abroad to become 'the slaves of the West'. The statistics show that more and more parents abandon their families and children to leave and work abroad, i.e. in Spain, Italy, Greece, Germany and England. Even if they can't get a job in these countries (or even if they can), most people prefer to stay abroad because they say that they wouldn't find a job in Romania. This phenomenon is common because nowadays many foreign companies try to employ Romanian people, and they can't get enough workers. The most important problem is represented by these parents' children who stay at home with or without any relatives. The phenomenon of the 'orphan' children with parents who are still alive is one of the most unexpected and dramatic that the Romanian family is now experiencing. For this reason, these children have countless absences from school, they are inclined to aggressiveness, committing crimes, taking drugs, tobacco, and alcohol. $85 \%$ of the children who go to a psychiatrist have at least one parent living abroad - the parents prefer paying for the treatments than coming back and staying with their children. Unfortunately, school has not solved the problem of inequality either, as failure is often linked to the social origin and, more recently, to the emigration phenomenon. The students who have learning difficulties are generally those who come from poor or modest families. It is difficult for the parents to hep their children learn because of the distance between them - even if the parents are willing to help, the distance is too significant. It encourages parents to 'educate through the telephone, or other technology'. This can be considered as a way of living because they can communicate very easily via Skype, Viber or Facebook. This communication is limited because it only allows verbal communacation - feelings or other direct contact cannot be put across.

In the short term, the parents' leaving impacts on a child's life. A child can show signs of verbal or physical aggressiveness, marginalization, anxiety, low marks, school skipping and even school abandoning. In the long run, this generation of children are deprived of their parents' love and of the family harmony. Many of them may experience difficulties when they are older. Also, there is the possibility that some of them will even become criminals. As a result the aggressiveness of many children belonging to the 'home alone' generation, their refusal to accept the fact that they have problems, and the pain caused by their parents' absence and leads them to become part of a generation of socially non-integrated adults in the future. The child that grows up without parents, or only with one of them, will become an adult who cannot understand the meaning of marriage and who does not trust the institution of marriage and people in general. More and more young people that go abroad to work in order to provide themselves a better life return home with serious psychological disorders.

The long period of time spent away from the family can create a crisis situation for the migrant person and their family. The negative effects can be noticed both at the level of the individual as a citizen abroad and at the family level. However, lots of people try to analyse things from another viewpoint. It is a nice thing to have the courage to enter another work market, to learn another language, to have access to another culture, to another system of values, to begin to assimilate into a society that is different from one's, but the possible risks associated to oneself, as an individual, and to one's social environment must be kept to a 
minimum. It is about the social relationships that one has until the moment of departing. However, these things are not always taken into account.

\section{Typology of the Learning Difficulties}

During school years, a child can show signs of poor language development. The most common of these are as follows:

- Dyslalia, which is a deviation from the usual pronunciation; the impossibility to make sounds or their omission; the replacement of some sounds with others; sound conversions;

- Stuttering is a more serious disorder that occurs more frequently among boys. There are three forms: chronic stammering - interruption of the fluency of speech due to extension or repetition of sounds and syllables; fluff note, this occurs when there is a blockage at the first word in the sentence due to an articulated, long-form spasm and mixed form;

- Delays in the overall development of the speech are met at those children who fail to attain the average level of speech as children of the same age. Such phenomenon is materialized into a poor vocabulary and low possibilities in the formulation of sentences and phrases. Delays in speech development may include both noise issues, but also lexical and grammatical ones.

- Elective dumbness (volunteer) - occurs frequently among hypersensitive children through a temporary, partial or total dumbness. Children refuse to communicate over a certain period of time with some people, and after a period of time, this can be a big problem, refusing to speak.

- Dyslexia and dysgraphia- refers to the inability to learn reading and writing. School children with such a disorder make constant and repeated confusion between letters and their grapheme; inversions, additions, omissions of letters and graphemes, omissions, inversions, additions of words and even sentences. A child with such a deficiency has difficulties communicating at the highest level of language. This feature prevents assimilation, internal storage and automatism of spelling rules. Because of the misunderstanding of readings and even their own hand writing, verbal language is not often expressed as it should be.

Infidelity of speech - a dysfunction caused by many factors. It is the disparity between the content and meaning.

Fantasy Play - is the child's ability to transform the real into surreal. It can negatively influence the learning process because the child's fantasy starts with physical or emotional needs.

All these coordinate the mental life of pupils, if acting together, decreasing the intellectual potential of the pupil and leading gradually to installment of mental deficiency in children. It is a psychological factor that causes school failure, inducing a decrease or a loss of cognitive functions. General intellectual activity is measured by a coefficient of intelligence (Q.I) by evaluating the results achieved in applying a standardized intelligence test administered individually. Following the research of A. Binet and Th. Simon (1904) "metric staircase" of intelligence has been developed and constantly updated. It specifics that there is a correlation between the age of the children and their mental age by establishing more or less deviations (degree of deviation) than the standard average of the age.

Emotionally speaking, referring to states, feelings and affective-attitudinal behavior of children with emotional disturbances, we intend to point out the following:

a) Shyness / Bashfulness - is commonly defined as a form of behavior characterized by lack of security, self-reliance, lack of boldness, fear, hesitation, defense reaction.

b) Anxiety - is resulting from a threat of self-respect, current or anticipated, based on underestimation of "inner-self ", lower self-evaluation; the most important feature of the anxious child is that she/he lives any situation that he/she is involved in as dangerous and 
never ceases to anticipate failure for each of their own activities no matter where this takes place.

c) Fear of school - is the most natural and common form of fear of separation. Once the first few months of transition to school attendance have passed and the fear of separation has not decreased but, on the contrary, intensifies and takes the form of having attacks of panic, then it is a symbolic type of fear called school phobia. Often, the cause of it is from a strong parent-child relationship, that it is more intense for mother than the child. The school begins to weaken the relationship of maternal dependency of the child, which plays an important role in their development up until the school age - but if maintained would have a negative influence on a child's future development. The child overestimates his/her skills, potential, performance, and the school threatens to scatter this belief, which is why she/he is heading towards preserving a situation which amplifies the image of their " inner-self " in a surreal and only apparently stimulating way.

d) Nervousness/Impatience - is often the way a child responds to the conditions and realities of life including school and family environments. The state of nervousness can be a short lined, without affecting the fundamental balance of the person. The environment can also be an influencing factor to a child's level of nervousness/impatience. Forms of expressions that shape the behavioral profile of the impatient and nervous child are varied: irritability, anger, hostility, depression, vulnerability, disturbances in food and sleep regime, psycho-motor instability, hysterical crises.

Children encounter motivation at difficulties like:

- The absence of intention to learn, lack of desire to achieve a specific purpose, which is either self-determined, or following explicit instructions from someone else.

- Inappropriate/ unrealistic expectation, that does not take into account the specific context in which the action is taking place.

- Lack of stimulation/ motivation - which may be due to objective or subjective factors, and which may cause many different effects regarding school activity.

- Lack of cognitive abilities (knowledge, abilities, skills, etc.) - leads to awareness of which often leads to lack of motivation, lack of care and participation, escape from the tasks/ responsibilities and, of course, to the appearance of learning difficulties and school failure.

The volitional act will be affected in the following ways:

- Negativism - is children's resistance to external or internal applications, which may take a passive position in which the child presents resistance to all requests or an active form that the opposite of the demands addressed to child. We may also include forms of stubbornness, interposing, spirit of resistance.

- Lack of persistence - is characterized by the inability of children to fight against the hardships that are in the way of achieving a goal or desire; or to do only what is pleasant, interesting from their point of view.

Studying the children's personality, involves getting to know and evaluate them in the correct manner. From the perspective of the school - the educational knowledge that is required. it needs to include formal qualities, dynamical - energetic (temper), socio-moral, character and attitudinal features. Immaturity of the character is derived from wrong doings in the educational process taking place in the family. Children can show a false understanding of moral concepts, appreciation of other people, facts and actions, or their own conduct, a total disagreement between moral knowledge and facts, views and conduct. Character Disorders express irregular development of personality, including negative social experiences in family and school life. 
Temper is a dynamic - energetic side of personality and is being expressed by the peculiarities of behavior (mobility and speech). Both emotiveness and activity are closely related to the "force" and "balance" of the nerve processes, characteristics which are obvious and relatively easy to be diagnosed. Behavioral disorders frequently occur in children who are excitable, nervous, with poor development and a weak control of the cortex of sub-cortical regions. For am adult (teacher or parent) it is important to determine whether a child is active or emotional. Because if a child shows they are inactive, he/she could be slow, lazy, and have no initiatives - factors that are described in the character disorders section. On the other hand, if the child has intense emotional reactions, they would be very involved in everything they do.

Another problem would be the negative attitudes towards education such as a lack of desire to fulfill the learning demands of the teachers, the lack of involvement, escape tasks, absences, resistance to the requests formulated by parents and teachers, violation of rules imposed by school and during classes, formal attending of teaching activities, without actual involvement/strive to understand explanations and content taught.

\section{The importance of teachers and schools in childrens' lives}

The only solution for solving these children's problems is to adapt the schools routine and educate teachers on children's learning difficulties. In these cases, the main requirement is organizing and conducting the learning process and individual learning strategies and methods for children with learning difficulties. In this respect, it is necessary for teachers to be knowledgeable of a range of teaching strategies - helping them to identify and support learning difficulties in the classroom. In our opinion, regardless of the school level, the fundamental requirements that teachers have to bear in mind are the following:

- to know the cross learning difficulties of each child, and also the specific learning difficulties in certain curricular areas and disciplines of study;

- to adapt the procedural and methodological resources to the specific learning difficulties in order to reduce non-effective learning and the appearance of the game of school;

- to purchase or create teaching aids when needed and use them especially to facilitate the learning process;

- to ensure every class has the necessary time to assess the effectiveness of the formative way of learning and teaching, thus supporting the efforts of children with learning difficulties and to adjust the conditions of learning (evaluation itself becomes a tool /aid for training).

Building a secure learning environment, appropriate and stimulating for all children including those who benefit from additional and more specialized support. This is one of the priorities when addressing the problems of children with learning difficulties. A secure environment provides children with learning difficulties psychological, allowing them to express themselves and build relationships.

This problem can't be solved only by the teachers. It is necessary for both sides to accept the help of some specialists, such as;

the psychological and pedagogical advisor (who deals with the general and specific learning problems at the individual and group levels) has in mind, in reference to the intervention issues, the following: the construction and the functionality of the general learning instruments (general and specific abilities, skills and capabilities) which focus on the attention, social and emotional inter-relationships, learning rhythm (slow or inappropriate), the use and the exercise of the logical and mathematical structures (argumentations, algorithms, the operationality of thinking), decision making, the conflict management, and the complex process of communication. and etc. The advisor's activities are meant for the students, teachers and parents, as well as for the necessary links between these actors of the education, in order to provide efficiency to the didactic process - both at the individual level 
and at the level of the class group and of the school/institution; the speech therapist deals with the detection, the complex examination and the personalized intervention in regards to the language difficulties and disorders ; the support teacher, the itinerant teacher and other didactic people, intervene to solve learning problems by various practical means integrating the children with special requirements or to support the normal school in fulfilling the tasks of the inclusive school (for all the children). Also, when it comes to directly intervening in the didactic activity, we have to think about the type of intervention that can support the didactic process and its protagonists. In the literature the things are not completely clarified (as the terminological delimitation of the learning difficulties is not either) - one speaks about new roles that the didactic staff can play in order to become: a resource teacher, a tutor, an advisory teacher, an itinerant teacher or a support teacher (amongst all these new kinds of teachers there is a link determined by the need of an intervention - in the classroom and outside the classroom - for solving the learning problems.

The parents notice some cognitive behaviours of their children from early ages and take their children to a specialist. They cooperate with all the people involved in the intervention, with an aim to recover, to compensate or to correct the learning difficulties.

An important way for solving the problems is the Personalized Intervention Plan, which teachers can make together with the other implicated persons. In this they must find out the right learning difficulty/difficulties and the ways that this/these can be deminished.

\section{CONCLUSIONS}

Although we cannot speak about an alarming number of children with school problems, there are many cases of children with poorer results, more absences, a lower grade for the behaviour, or simply cases of children who have no pleasure in attending school. For the children whose parents have left to work abroad, school represents an important factor of stress. As an operational method for acting, the establishment of the differential diagnosis is very important. The child with learning difficulties may be recuperated if they attend personalised intervention programmes which carefully include; objectives, proper recuperation activities, specific methods and means, and the duration of each activity is considered as well as the forms of the periodical and final evaluations.

\section{REFERENCES}

Catalano. H. (2008). Migraţia - o nouă cauză a dificultăţilor de învăţare în şcoala contemporană. în Revista „Educaţia 21” editată de Institutul de Pregătire Didactică a Universităţii Babeş-Bolyai Cluj-Napoca.

Catalano. H. (2009). Dificultăţile de învăţare transversale. Program de intervenţie educaţională pentru elevii cu părinţi emigranţi. Editura Paralela 45. Piteşti.

Catalano. H. (2009). Fenomenul migraţiei. Consecinţe socio-educaţionale. în Instrucţie şi educaţie în şcoala contemporană. Editura EUROTUR-13-2000. Bucureşti.

Catalano. H. (2009). Abordarea psihopedagogică a dificultăţilor de învăţare. Implicaţii la nivelul diferitelor componente ale personalităţii. în Revista „Educaţia 21”. editată de Institutul de Pregătire Didactică a Universităţii Babeş-Bolyai Cluj-Napoca.

Catalano. H. (2013). Programul de intervenţie educaţională ca instrument al adaptării curriculare. în Abordări curriculare. Aplicaţii în învăţămăntul incluziv. Editura Eikon. Cluj-Napoca.

Cerghit. I. (1983). Perfecţionarea lecţiei în şcoala modernă. Editura Didactică şi Pedagogică. Bucureşti. 
Dragomirescu. V. (1976). Psihosociologia comportamentului deviant. Editura Ştiinţifică şi Enciclopedică. Bucureşti.

Gherguţ. A. (2005). Sinteze de psihopedagogie specială. Editura Polirom. Iaşi.

Ieniştea. O. (1982). Dificultăţi la învăţătură. Editura Medicală. Bucureşti.

Kelemen. G. (2007). Copilul cu dificultăţi de învăţare. Editura Universităţii „Aurel Vlaicu”. Arad.

Neacşu. I. (1978). Motivaţie şi învăţare. Studiu asupra motivelor învăţării şcolare în ciclul gimnazial. Editura Didactică şi Pedagogică. Bucureşti.

Păunescu. C. (1977). Deficienţa mintală şi organizarea personalităţii. Editura Didactică şi Pedagogică. Bucureşti.

Vrăşmaş. E.A. (2007). Dificultăţile de învăţare în şcoală. Editura V\&I Integral. Bucureşti.

Ungureanu. D. (1995). Copiii cu dificultăţi de învăţare. Editura Didactică şi Pedagogică. Bucureşti. 